\title{
Factors affecting the intention to use e-Government services
}

\author{
Prodromos Chatzoglou \\ Democritus University of Thrace, \\ Department of Production and \\ Management Engineering, \\ Vasillisis Sofias 12, 67100, \\ Xanthi, Greece \\ Email: pchatzog@pme.duth.gr
}

\author{
Dimitrios Chatzoudes \\ Democritus University of Thrace, \\ Department of Production and \\ Management Engineering, \\ Vasillisis Sofias 12, 67100, \\ Xanthi, Greece \\ Email: dchatzoudes@yahoo.gr
}

\author{
Symeon Symeonidis \\ Democritus University of Thrace, \\ Department of Electrical and \\ Computer Engineering, \\ Vasillisis Sofias 12, 67100, \\ Xanthi, Greece \\ Email: ssymeoni@ee.duth.gr
}

\begin{abstract}
Nowadays, more and more people are using Information and Communication Technologies (ICTs) in order to accommodate their daily needs. E-Government (e-Gov) adopts these technologies in an effort to provide prompt and secure services to citizens. However, the intention to use eGovernment services has not yet been fully examined by the international literature. The present research attempts to bridge this gap, by examining the factors affecting citizens' intention to use e-Government services. In that direction, a conceptual framework (research model), based on an extensive review of the relevant literature, has been developed. The proposed conceptual framework has been empirically tested using a newly-developed structured questionnaire. Data were collected from a sample of 547 Greek citizens. The reliability and the validity of the questionnaire have been thoroughly examined, while the Structural Equation Modeling (SEM) technique has been used to analyze the data. Results indicate that perceived usefulness is the most important determinant of the intention to use e-Government services. Other important factors are perceived trust, internet experience, peer influence, computer self-efficacy and perceived risk.
\end{abstract}

\section{INTRODUCTION}

$\mathrm{D}$ URING the last 15 years, information and communication technologies (ICTs) play a central role in the global digital economy and are considered key tools of worldwide administrative reforms [1]. e-Government (eGovernance and / or e-Gov) is defined as "an initiative aimed at reinventing how the government works and improving the quality of interactions with citizens and businesses through improved connectivity, better access, furnishes high quality services and better processes and systems" [2]. Moreover, according to Ziemba, Papaj and Jadamus-Hacura [3], e-Government "suggests the use of information and communication technology (ICT) to provide efficient and quality government services to employees, government units at the state and local levels, and to citizens and businesses".

At the same time, official states (governments) are using e-Government in order to improve public services and strengthen political processes.
The intention of citizens to use e-Government services has been investigated by several previous studies [1] [2] [3]. Despite that, these studies have not reached consensus, while most of their empirical results are quite obvious (investigating already established concepts and validating ideas that have already been proven valid). Simultaneously, in the practical level, there have been many failed and costly attempts in developing citizen acceptance concerning e-Government services [1] [2].

The main objective of the present paper is to investigate the factors that have an impact on citizens' intention to use e-Government services. The proposed conceptual framework takes under consideration a bundle of factors that have never been collectively examined before. Its significance lies in the depth of its results, conclusions and empirical implications.

The following section attempts a brief literature review, while sections three and four include the presentation of the proposed conceptual framework and the research hypothesis. In the fifth section, the research methodology is being presented, while the paper is concluded with its main results and conclusions (sections six and seven respectively).

\section{LITERATURE REVIEW}

Many different definitions of e-Government can be found in the relevant literature. According to Sang, Lee and Lee [4], e-Government is based on ICTs and aims to achieve better governance. Carter and Bélanger [5] and Bekkers [6] argued that e-Government includes initiatives transforming government services and increasing their quality. Moreover, Doong, Wang and Foxall [7] underline the importance of technology in altering citizen behavior, while arguing that eGovernment is a competitive tool for achieving higher efficiency of state affairs. However, these advantages can only be achieved if the technology is widely accepted [7]. Therefore, it is important to examine the determinants of acceptance and, hence, present the relevant theoretical models. 


\section{A. Theoretical background}

Diffusion of Innovation (DOI): According to DOI theory, the use of technology is a decision based on compatibility, relative advantage, social pressure and communication [8]. Phang, Li, Sutanto and Kankanhalliet [9] observed that the elderly are willing to learn and use new technologies that are accompanied by changes in the structure of the society. This is because the adoption of the technology can enhance the social status of the individual and play a positive role in assisting others to adopt the innovation themselves [2] [8].

Theory of Reasoned Action (TRA): The TRA is one of the first theories explaining the behavior, use and acceptance of computer technology. Three constructs are the main components of TRA: behavioral intention (BI), attitude (A), and subjective norm (SN). According to TRA, a person's behavioral intention depends on his attitude about the behavior, and his subjective norms $(\mathrm{BI}=\mathrm{A}+\mathrm{SN})$ [11] [12].

Theory of planned behavior (TPB): The TPB has been proposed as an extension of TRA [13]. The elements of behavior and subjective norm are the same in TPB, as in TRA. The difference is that the TPB includes additional determinants of intention (more specifically, perceived behavioral control and self-efficacy). These modifications have increased the explanatory power of TPB.

Technology Acceptance Model (TAM) and TAM2: TAM builds upon the causal relationships of TRA in order to explain the technology acceptance behavior [10]. It suggests that perceived usefulness (PU) and perceived ease of use (PEOU) are the main determinants of technology adoption. TAM2, an extension of the initial model, incorporated additional constructs, such as social influence, subjective norms, voluntarism, social status, as well as cognitive processes, such as labor relevance, quality production and perceived ease of use [2].

Motivational model: Deci [13] focused on intrinsic motivation and argued that external motives do not have a significant persuasive power, in case the individual does not receive pleasure by the use of said technology [14].

Model of PC utilization: Thompson, Higgins and Howellet [16] argued that complexity, long-term benefits, social factors and facilitating conditions are determinants of computer use [15].

Social cognitive theory: Social cognitive theory argues that acquiring individual knowledge is directly related to observing others within the context of social interactions and experiences [4] [17] [18].

Unified Theory of Acceptance and Use of Technology (UTAUT): The UTAUT model was based on all previous theories. In comparison with previous models, UTAUT explains $70 \%$ of the variance in technology acceptance, a significant improvement from previous models (that only explained $40 \%$ of the same variance) [2]. Hence, UTAUT is considered as an enhanced model with robust features.

\section{B. Diffusion of innovation and e-Government adoption}

The innovation diffusion theory was first systematically tested in the 1940s and has evolved exponentially since then [20]. According to Rogers [8], "innovation is an idea, practice, or object that is considered new by an individual or another unit of acceptance". Based on this definition, the use of e-Government services is a new practice and can be considered as an innovation for each individual user.

The diffusion of innovation theory suggests a general model including five groups of recipients, based on how early they start to use a specific innovation [21]. The five categories of recipients are: innovators, early recipients, early majority, slow majority, and laggards [21]. Each group has different characteristics.

Following the categories proposed by the diffusion of innovation theory, people who already use e-Government services can be perceived as early recipients. The diffusion of innovation theory presumes that early recipients share certain characteristics (young age, higher education and income) [21]. Previous studies conducted in the field of public administration have shown that people who use electronic public services fit this description [20] [22].

Atkin, Jeffres and Neuendorfet [23] compared internet adopters and non-adopters, using the following criteria: social status, communication needs, media use, and relation with technology. It was hypothesized that internet adopters will differ from non-adopters in specific demographics (age, education, income). Furthermore, internet adopters would be more cosmopolitan, would have increasing communication needs, and would be more interested in experimenting with new technologies. Indeed, the profile of early adopters showed that they followed the theory of diffusion of innovation, confirming all differences on demographic levels and use of technology [23].

\section{Previous studies}

Lean, Zailani, Ramayah and Fernando [2] investigated the factors that influence the intention of Malaysian citizens to use e-government services. They developed a model incorporating factors from both DOI and TAM, while also taking under consideration various cultural factors, as well as trust. Their study included 150 participants. Empirical results revealed that trust, perceived usefulness, perceived relative advantage and perceived image have a direct positive effect on the intention to use e-Government services. On the other hand, perceived complexity was found to have a negative effect on intention. Lean, Zailani, Ramayah and Fernando [2] finally argued that, while online privacy has a positive impact on e-government usage, no significant effect exists between innovation factors (complexity, comparative advantage and image) and intention. Finally, they underlined that DOI has a better explanatory power than all the other employed models [2]. 
In another similar study, Wangpipatwong, Chutimaskuland and Papasrator [1] explored the factors affecting the intention of citizens to use e-Government websites. They used TAM as the basis of their research model, while the ability to use computers was incorporated as an additional factor affecting intention. A web-based survey was used to empirically test the proposed research model. The participants of the survey were 614 , while each of them had (at least) a university degree and experience in visiting eGovernment websites. Results revealed that perceived usefulness, perceived ease of use, privacy and the ability to use computers, directly enhance the intention to use eGovernment websites [1]. However, it was concluded that different factors have different effect on intention. More specifically, perceived usefulness and ease of use seemed to be more important than the ability to use computers [1].

The effect of perceived risk and perceived trust on the willingness to use e-Government services was examined by Bélanger and Carter [24]. They proposed a model consisting of trust propensity, trust on the internet (TOI), trust on the government (TOG) and perceived risk. Empirical results revealed that trust propensity has a positive impact on both TOI and TOG, which in turn have a positive effect on intention to use e-Government services. Moreover, TOG negatively affects perceived risk, which in turn has a negative impact on intention. The proposed model of Bélanger and Carter [24] is a step towards identifying the unique elements of trust and risk in the e-Government literature [24].

Colesca [25] tried to identify the factors affecting public confidence towards e-government services. The study was conducted in Romania and the sample was 793 citizens. Empirical findings revealed that technical and organizational reliability, perceived quality, perceived usefulness, internet experience and trust propensity directly enhance eGovernment usage. On the other hand, age and privacy concerns had a negative impact [25].

In another similar empirical study, Hung, Chang and $\mathrm{Yu}$ [26] examined the factors that determined the acceptance of the online submission system of tax declarations and payments (OTFPS) in Taiwan. The authors [26] developed a research model based on the theory of planned behavior. The study was conducted using a survey of 1099 citizens. Results showed that the proposed model explained $72 \%$ of the variance in usage behavior. More specifically, user acceptance of OTFPS was influenced by perceived usefulness, perceived ease of use, risk perception, trust, compatibility and peer pressure [26].

Sang, Lee and Lee [4] found that perceived usefulness, relative advantage and trust are significant predictors of eGovernment adoption in Cambodia. Moreover, it was discovered that the determinants of perceived usefulness include image and output quality.
Finally, the empirical results provided by Dashti, Benbasat and Burton-Jones [27] demonstrate the significant role of trust on e-Government usage. More specifically, their study provided evidence supporting the relationships between 'felt trust' by e-Government, trust in e-Government, and intention to use e-Government websites [27].

\section{CONCEPTUAL FRAMEWORK}

The proposed conceptual framework was developed after an extensive review of the existing relevant literature. Previous studies have been thoroughly examined and the most significant factors have been utilized in the proposed framework. Therefore, the present study offers a critical synthesis of existing empirical work on e-Government adoption. It adopts a holistic approach, unifying previous findings into an extensive conceptual framework.

The factors that have been used in the present study are briefly described in the following paragraphs.

\section{A. Perceived risk}

For the past five decades, the theory of perceived risk is an important research agenda of consumer behavior. Perceived risk is defined as a concept of expected subjective injury [30] as well as desirable effect [31]. The literature [32] suggests that six types of perceived risk really exist. These types may vary, depending on the service or product. In the present study five types of risks are being incorporated in the proposed framework:

Performance risk: It concerns the risk of e-Government services not performing as they should be. For example, an electronic failure may result in unexpected losses [33].

Financial risk: According to Kuisma, Laukkanen and Hiltunenet [33] a transaction error or a misuse of the user's private information may bring economic consequences, thus, resulting in fear of conducting any transactions.

Social risk: It is regarded as the possibility of the purchase or use to provoke negative judgment by other members of the society (external psychological risk) [30].

Time risk: It is the risk relating to the user's loss of time during a transaction. The delay in loading the website and a disorganized site may be considered time delay causes [34].

Security risk: It is the risk of losing sensitive personal data during a transaction [35]. A breach of confidentiality is a usual fear during on-line transactions [36].

\section{B. Trust in e-Government}

Trust is a factor that has been extensively investigated and defined in various differently ways. According to Rotter [42], trust is considered as "the expectancy that the promise of a person or group can be relied upon". Trust in the context of e-Government is measured through two dimensions: trust in the particular entity (which, in this case, is the government), and trust in the reliability of the enabling technology (which, in this case, is the internet) [24]. 


\section{Perceived usefulness}

Perceived usefulness is the degree in which someone believes that using a particular system would enhance his or her job performance [11].

\section{Perceived ease of use}

According to Davis [11], perceived ease of use can be defined as the degree in which someone believes that using a particular system would be free from effort [40].

\section{E. Perceived quality}

Aaker [46] defined perceived quality as the consumer perception of the overall quality or superiority of a product (or a service) in relation to other alternatives. Perceived quality is different from tangible (real) quality, which is embedded in the manufacturing process [46]. No matter how high the level of every product's manufacturing quality, consumers are the ones that will determine its (perceived) quality in the marketplace.

\section{F. Quality of internet connection}

Sathye [41] considered quality of the internet connection as one of the significant factors affecting the adoption of various electronic transactions.

\section{$G$. Internet experience}

According to Eastlick and Lotz [37], the history of a user's behavior can positively affect the likelihood of adopting the same behavior in the future. Internet use is positively affected by internet experience [38].

\section{H. Computer self - efficacy}

Computer self-efficacy is defined as the perception of an individual concerning his ability to use computers in order to conduct a certain task [45]. People with a high level of computer self-efficacy are able to efficiently use different software packages and computer systems, while those with a low level of computer self-efficacy perceive their potential as quite limited [45].

\section{Self-image}

Venkatesh and Davis [10] defined 'image' as the degree to which the use of an innovation enhances the social status of an individual. A person is more likely to engage in an activity, if the activity is approved by others [5].

\section{J.Peer influence}

Peer influence is the effect of the immediate environment on the behavior of the individual [14]. Peer influence (or peer pressure) encourages others to change their attitudes in order to conform to group norms.

\section{$K$. Intention to use}

'Intention to use' is the main dependent factor of the present study, measuring the intention of citizens to use eGovernment services [10].

\section{RESEARCH HYPOTHESES}

The present study includes ten independent and one dependent factor. The relationships between these factors are analytically presented in the following paragraphs.

\section{A. Perceived risk and intention to use}

Lee [49] has found that security risk (privacy risk) and financial risk have a negative effect on the intention to use online banking. In the same direction, Pires, Stanton and Eckford [50] argued that there is a negative correlation between perceived risk and intention to use web applications. Hence, it is hypothesized:

$\mathrm{H} 1$ : Perceived risk has a negative effect on the intention to use e-Government services.

\section{B. Trust in e-Government and intention to use}

According to the empirical results of a study conducted by Carter and Bélanger [5], trust is a significant predictor of the intention to use e-government services. In another similar study, the same authors [24] found out that disposition to trust positively affects trust towards the internet and trust towards the government, which in turn affect the intentions to use e-Government services. Dashti, Benbasat and Burton-Jones [27] also showed that trust for eGovernment is an important factor that increases its use.

H2: Trust in e-Government has a positive effect on the intention to use e-Government services.

\section{Perceived usefulness and intention to use}

The relationship between perceived usefulness and intention to use has been widely acknowledged by the empirical literature [20, 23, 47]. Davis [11] revealed that perceived usefulness is a key factor in the intention to use web system applications. It is only logical to assume that:

H3: Perceived usefulness has a positive effect on the intention to use e-Government services.

\section{Perceived ease of use and intention to use}

As in the case of perceived usefulness, perceived ease of use has been found to have a positive effect on intention to use [2, 4, 10]. For example, Gefen and Straub [40] and Davis [11] argued that perceived ease of use is positively related to the use of present and future technology. Based on the above, it is hypothesized that:

H4: Perceived ease of use has a positive effect on the intention to use e-Government services.

\section{E. Perceived quality and intention to use}

Colesca [25] suggests that the higher the perception of quality of an electronic service, the higher the level of trust towards that service and, consequently, the intention to use it. Moreover, Gronier and Lambert [48] argue that eGovernment quality enables citizens to directly locate the services they need, thus, achieving higher levels of satisfaction and effectiveness. Therefore, it is hypothesized: 
H5: Perceived quality has a positive effect on the intention to use e-Government services.

\section{F. Quality of internet connection and intention to use}

Sathye [41] argued that internet access is one of the most important factors for the acceptance of electronic banking. Without a proper internet connection it is impossible to use electronic services [41]. Moreover, Pikkarainen, Pikkarainen, Karjaluoto and Pahnilaet [51] found out that a decent internet connection has significant influence on the intention to use e-Government services.

H6: Quality of the internet connection has a positive effect on the intention to use e-Government services.

\section{$G$. Internet experience and intention to use}

Based on their empirical results, Corbitt, Thanasankit and Yi [52] argued that prior internet experience has a positive influence on the intention to shop online. Cho [53] reached the same conclusion, stating that experienced internet users are more likely to conduct an online transaction when they feel the urge to do so. It would be interesting to examine whether that is also the case with e-Government services.

H7: Internet experience has a positive effect on the intention to use e-Government services.

\section{H. Computer self-efficacy and intention to use}

Wangpipatwong, Chutimaskul and Papasrator [1] empirically confirmed that the adoption of e-government depends upon the ability to use a computer.

H8: Computer self-efficacy has a positive effect on the intention to use e-Government services.

\section{Self-image and intention to use}

Sang, Lee and Lee [4] have found out that individuals adopt an innovation in order to impress others that have not adopted it. On the other hand, Carter and Bélanger [5] failed to establish such a relationship, reporting that high levels of self-image do not directly affect the intention to use eGovernment services. Therefore, it would be interesting to examine which is the case, adopting the hypothesis that:

H9: Self-image has a positive effect on the intention to use e-Government services.

\section{J.Peer influence and intention to use}

According to Hung, Chang and $\mathrm{Yu}$ [26], peer influence is a key factor in using online tax applications. Moreover, Taylor and Todd [54] support that peer influence is an important determinant of Information System (IS) adoption. Since e-Government has the characteristics of these systems, it is only logical to hypothesize that:

H10: Peer Influence has a positive effect on the intention to use e-Government services.
Fig. 1 summarizes the above hypotheses, thus, presenting the proposed Conceptual Framework of the study.

\begin{tabular}{|c|c|c|}
\hline \multirow{2}{*}{ Perceived risk } & H1(-) & \\
\hline & \multirow{2}{*}{$H 2(+)$} & \\
\hline Trust in e-Government & & \\
\hline Perceived usefulness & $H 3(+)$ & \\
\hline & \multirow[t]{2}{*}{$\mathrm{H} 4(+)$} & \\
\hline Perceived ease of use & & \\
\hline Perceived quality & \multirow{2}{*}{\begin{tabular}{|l}
$H 5(+)$ \\
$H 6(+)$
\end{tabular}} & \multirow{3}{*}{$\begin{array}{c}\text { Intention to use e- } \\
\text { Government } \\
\text { services }\end{array}$} \\
\hline Ouality of internet connection & & \\
\hline \multirow{2}{*}{ Internet experience } & $H 7(+)$ & \\
\hline & \multirow{2}{*}{$H 8(+)$} & \\
\hline Computer self-efficacy & & \\
\hline Self-image & $H 9(+)$ & \\
\hline Peer influence & $H 1 O(+)$ & \\
\hline
\end{tabular}

Fig. 1 The proposed conceptual framework of the study

\section{RESEARCH METHODOLOGY}

\section{A. The population of the study}

The proposed conceptual framework was tested with the use of a newly-developed structured questionnaire on a sample of Greek internet users. Hence, internet users living in Greece are the population of the present study. According to reliable data [58], internet users in Greece have reached 6.451 .326 in December of 2013 (55,9\% of the population).

Since the main dependent factor of the study is "intention to use e-Government services", respondents could be: (a) inexperienced e-Government users (non-users), (b) one-time e-Government users (not continual users), or (c) continual users. The sample of the study included individuals from the last two categories.

\section{B. Measurement}

The measurement of each of the eleven factors of the proposed conceptual framework was conducted with the use of multiple questions (items) that were adopted from the international literature. The five point Likert scale was used for the measurement of all factors. Table I demonstrates the eleven factors of the study, the number of items used in each case and the studies from which they where adopted.

\section{Data collection}

Primary data were collected from a random sample of internet users. The only criterion for citizens to participate in the survey was the use of internet. Personal interviews were conducted in order to collect the appropriate data. Citizens were selected in random (using the systematic sampling approach). The research period lasted two months (May to July 2013). Totally, 566 questionnaires were returned and 547 were used for data analysis. 
TABLE I. FACTOR MEASUREMENT

\begin{tabular}{|l|c|c|}
\hline Factors & Items & Source \\
\hline Perceived risk & 11 & 48,49 \\
\hline Trust in e-Government & 15 & $4,23,26$ \\
\hline Perceived usefulness & 4 & $10,46,55$ \\
\hline Perceived ease of use & 4 & $10,39,46$ \\
\hline Perceived quality & 4 & 24 \\
\hline Quality of internet connection & 4 & 40,50 \\
\hline Internet experience & 3 & 51,52 \\
\hline Computer self-efficacy & 3 & 1 \\
\hline Self-image & 4 & 3,4 \\
\hline Peer influence & 4 & 25 \\
\hline Intention to use & 4 & 46,54 \\
\hline Total & 60 & \\
\hline
\end{tabular}

\section{Reliability and validity}

The instrument (questionnaire) that was used in the present study was tested for both its content and construct validity. The test for the content validity was conducted using a pilot study approach. Twenty (20) citizens were asked to fill in the final draft of the questionnaire and make comments concerning their level of understanding. Citizens' comments improved various aspects of the questionnaire (e.g. use of language).

For the control of the construct validity, each of the eleven research factors was evaluated: (a) for its unidimensionality and reliability (Table II), (b) for its goodness of fit to the proposed research framework (Table III).

The examination of the unidimensionality of each of the research factors was conducted using Explanatory Factor Analysis (EFA). Moreover, for the estimation of the reliability of these factors, Cronbach Alpha was used. All tests concluded that the scales used are valid and reliable (see Table II above for the main results).

The evaluation of the goodness of fit of each research factor to the proposed model was conducted using Confirmatory Factor Analysis (CFA). All tests produced satisfactory results (see Table III above for the main results).

It should be noted that Second Order CFA was conducted for the five dimensions of risk (performance risk, financial risk, social risk, time risk, security risk). All statistical measures extracted from this analysis where within satisfactory levels.
TABLE II. ESTIMATION OF UNIDIMENSIONALITY AND RELIABILITY

\begin{tabular}{|l|c|c|c|c|c|}
\hline \multicolumn{1}{|c|}{ Factors } & KMO & $\begin{array}{c}\text { Bartlett's } \\
\text { Test }\end{array}$ & $\begin{array}{c}\text { Eigen- } \\
\text { value }\end{array}$ & TVE & $\begin{array}{c}\text { Cronbach } \\
\text { Alpha }\end{array}$ \\
\hline Perceived risk & 0,82 & $1843,2^{\mathrm{a}}$ & 1,201 & $59,1 \%$ & 0,785 \\
\hline $\begin{array}{l}\text { Trust in e- } \\
\text { Government }\end{array}$ & 0,70 & $595,9^{\mathrm{a}}$ & 2,195 & $73,1 \%$ & 0,817 \\
\hline $\begin{array}{l}\text { Perceived } \\
\text { usefulness }\end{array}$ & 0,81 & $1624,9^{\mathrm{a}}$ & 3,174 & $79,3 \%$ & 0,913 \\
\hline $\begin{array}{l}\text { Perceived ease of } \\
\text { use }\end{array}$ & 0,81 & $1680,9^{\mathrm{a}}$ & 3,181 & $79,5 \%$ & 0,914 \\
\hline $\begin{array}{l}\text { Perceived quality } \\
\text { Quality of internet } \\
\text { connection }\end{array}$ & 0,79 & $935,6^{\mathrm{a}}$ & 2,701 & $67,5 \%$ & 0,839 \\
\hline $\begin{array}{l}\text { Internet } \\
\text { experience }\end{array}$ & 0,69 & $466,5^{\mathrm{a}}$ & 2,076 & $69,2 \%$ & 0,773 \\
\hline $\begin{array}{l}\text { Computer self- } \\
\text { efficacy }\end{array}$ & 0,71 & $751,6^{\mathrm{a}}$ & 2,309 & $76,9 \%$ & 0,850 \\
\hline Self-image & 0,73 & $1191,6^{\mathrm{a}}$ & 2,548 & $84,9 \%$ & 0,911 \\
\hline Peer influence & 0,70 & $511,7^{\mathrm{a}}$ & 2,128 & $70,9 \%$ & 0,791 \\
\hline Intention to use & 0,72 & $674,1^{\mathrm{a}}$ & 2,265 & $75,4 \%$ & 0,837 \\
\hline
\end{tabular}

TABLE III. ESTIMATION OF THE GOODNESS OF FIT

\begin{tabular}{|l|c|c|c|c|c|}
\hline \multicolumn{1}{|c|}{ Factors } & $\begin{array}{c}\text { Normed } \\
\mathbf{X}^{2}\end{array}$ & C.R. & V.E. & $\begin{array}{c}\text { RMSE } \\
\mathbf{A}\end{array}$ & $\begin{array}{c}\text { CFI } / \\
\text { GFI }\end{array}$ \\
\hline Perceived risk & 2,49 & 0,84 & $78,8 \%$ & 0,091 & $\begin{array}{c}0,99 / \\
0,97\end{array}$ \\
\hline Trust in e-Government & 3,67 & 0,73 & $67,3 \%$ & 0,093 & $\begin{array}{c}0,93 / \\
0,95\end{array}$ \\
\hline Perceived usefulness & 3,34 & 0,61 & $55,6 \%$ & 0,089 & $\begin{array}{c}0,94 / \\
0,96\end{array}$ \\
\hline Perceived ease of use & 2,32 & 0,77 & $71,7 \%$ & 0,077 & $\begin{array}{c}0,97 / \\
0,97\end{array}$ \\
\hline Perceived quality & 2,53 & 0,64 & $75,1 \%$ & 0,094 & $\begin{array}{c}0,99 / \\
0,99\end{array}$ \\
\hline Quality of internet \\
connection & 4,11 & 0,82 & $69,4 \%$ & 0,091 & $\begin{array}{c}0,91 / \\
0,93\end{array}$ \\
\hline Internet experience & 2,43 & 0,83 & $78,7 \%$ & 0,079 & $\begin{array}{c}0,93 / \\
0,99\end{array}$ \\
\hline Computer self-efficacy & 3,43 & 0,77 & $69,5 \%$ & 0,082 & $\begin{array}{c}0,99 / \\
0,99\end{array}$ \\
\hline Self-image & 2,93 & 0,68 & $73,7 \%$ & 0,099 & $\begin{array}{c}0,91 / \\
0,94\end{array}$ \\
\hline Peer influence & 1,97 & 0,84 & $69,3 \%$ & 0,095 & $\begin{array}{c}0,97 / \\
0,99\end{array}$ \\
\hline Intention to use & 3,43 & 0,88 & $89,2 \%$ & 0,084 & $\begin{array}{c}0,93 / \\
0,97\end{array}$ \\
\hline
\end{tabular}

\section{RESULTS}

\section{A. Basic measures}

The examination of the proposed conceptual framework was conducted with the use of the "Structural Equation Modeling" (SEM) technique [59] [60]. 
To evaluate the fit of the (modified) overall model the chi-square value $\left(X^{2}=99,9\right.$ with 26 degrees of freedom) and the $p$-value $(p=0,0356)$ were estimated. These values indicate a satisfactory fit of the data to the overall model. However, the sensitivity of the $\mathrm{X}^{2}$ statistic to the sample size requires the use of other supplementary measures of evaluating the overall model, such as the "Normed- $\mathrm{X}^{2 \text { ", }}$ index $(3,84)$, the RSMEA index $(0,071)$ the CFI $(0,94)$ and the GFI $(0,96)$, that all indicate a very good fit. Additionally, the Construct Reliability (C.R.) and the Variance Extracted (V.E.) for all factors (constructs) are satisfactory.

\section{B. Hypothesis testing}

As it can be seen on Table IV, six of the originally hypothesised paths were found significant $(\mathrm{H} 1, \mathrm{H} 2, \mathrm{H} 3, \mathrm{H} 7$, H8, H10), while thirteen new paths (presented on Figure II with dashed lines) were added to the model, based on the modification indexes function of AMOS. Moreover, two factors (quality of internet connection and self-image) were completely discarded from the model, while for four hypotheses (H4, H5, H6, H9) no statistical support was provided (although $\mathrm{H} 4$ is supported when indirect effects are considered).

The above modifications resulted in a modified structural model with improved fit (as already explained above). In more detail, the factors that are included in the final model can explain $52 \%$ of the variance in the dependent variable, i.e. intention to use e-Government services.

The modified conceptual framework presents an interesting view of the subject under consideration, arguing that every factor is significant in enhancing e-Government usage, either directly or indirectly. For example, perceived ease of use does not have a direct impact on intention, but it has an indirect effect, through perceived risk and perceived usefulness. On the other hand, perceived usefulness has both a direct and indirect effect on intention. Moreover, perceived quality does not seem to have any effect on intention whatsoever.

\section{Further analysis}

The following observations can be made after reviewing the empirical results of the study (see Table IV and Fig. 2):

- Perceived usefulness directly affects intention. This is also confirmed by the Technology Acceptance Model (TAM) of Davis [11]. Moreover, this impact is not only statistical significant, but is also quite strong $(\mathrm{r}=0,51)$.

- Additionally, trust in e-Government has a significant direct effect on intention. The same conclusion has been drawn by Bélanger and Carter [24] and Colesca [25]. According to these authors [24] [25], when the user actually believes that the transaction and his personal data are secure, it is more likely to experience a higher level of intention to use the online services.
TABle IV. Results of THE Modified Structural Model

\begin{tabular}{|c|c|c|c|c|}
\hline \multicolumn{2}{|r|}{ Causal Paths (hypotheses) } & \multirow{2}{*}{$\begin{array}{c}\text { Estimate } \\
-0,10\end{array}$} & \multirow{2}{*}{\begin{tabular}{c|}
$\mathbf{p}$ \\
0,000
\end{tabular}} & \multirow{2}{*}{$\begin{array}{c}\text { Result } \\
\text { Accepted }\end{array}$} \\
\hline $\mathrm{H} 1$ & $\begin{array}{l}\text { Perceived risk } \rightarrow \\
\text { Intention to use }\end{array}$ & & & \\
\hline $\mathrm{H} 2$ & $\begin{array}{l}\text { Trust in e-Government } \rightarrow \\
\text { Intention to use }\end{array}$ & 0,25 & 0,000 & Accepted \\
\hline $\mathrm{H} 3$ & $\begin{array}{l}\text { Perceived usefulness } \rightarrow \\
\text { Intention to use }\end{array}$ & 0,51 & 0,000 & Accepted \\
\hline $\mathrm{H} 7$ & $\begin{array}{l}\text { Internet experience } \rightarrow \text { Intention } \\
\text { to use }\end{array}$ & 0,13 & 0,000 & Accepted \\
\hline H8 & $\begin{array}{l}\text { Computer self-efficacy } \rightarrow \\
\text { Intention to use }\end{array}$ & 0,10 & 0,000 & Accepted \\
\hline $\mathrm{H} 10$ & $\begin{array}{l}\text { Peer influence } \rightarrow \\
\text { Intention to use }\end{array}$ & 0,12 & 0,000 & Accepted \\
\hline \multicolumn{2}{|r|}{ New causal paths } & & & \\
\hline & $\begin{array}{l}\text { Perceived ease of use } \rightarrow \\
\text { Perceived risk }\end{array}$ & $-0,22$ & 0,000 & \multirow{12}{*}{$\begin{array}{l}\text { New } \\
\text { paths }\end{array}$} \\
\hline & $\begin{array}{l}\text { Perceived ease of use } \rightarrow \\
\text { Perceived usefulness }\end{array}$ & 0,42 & 0,000 & \\
\hline & $\begin{array}{l}\text { Perceived ease of use } \rightarrow \\
\text { Perceived quality }\end{array}$ & 0,13 & 0,000 & \\
\hline & $\begin{array}{l}\text { Computer self-efficacy } \rightarrow \\
\text { Perceived ease of use }\end{array}$ & 0,26 & 0,000 & \\
\hline & $\begin{array}{l}\text { Trust in e-Government } \rightarrow \\
\text { Perceived risk }\end{array}$ & $-0,20$ & 0,000 & \\
\hline & $\begin{array}{l}\text { Trust in e-Government } \rightarrow \\
\text { Perceived quality }\end{array}$ & 0,42 & 0,000 & \\
\hline & $\begin{array}{l}\text { Perceived usefulness } \rightarrow \\
\text { Trust in e-Government }\end{array}$ & 0,25 & 0,000 & \\
\hline & $\begin{array}{l}\text { Perceived usefulness } \rightarrow \\
\text { Perceived quality }\end{array}$ & 0,22 & 0,000 & \\
\hline & $\begin{array}{l}\text { Internet experience } \rightarrow \\
\text { Perceived ease of use }\end{array}$ & 0,61 & 0,000 & \\
\hline & $\begin{array}{l}\text { Internet experience } \rightarrow \\
\text { Computer self-efficacy }\end{array}$ & 0,76 & 0,000 & \\
\hline & $\begin{array}{l}\text { Internet experience } \rightarrow \\
\text { Perceived risk }\end{array}$ & $-0,10$ & 0,000 & \\
\hline & $\begin{array}{l}\text { Peer influence } \rightarrow \\
\text { Perceived usefulness }\end{array}$ & 0,16 & 0,000 & \\
\hline
\end{tabular}

- Internet experience directly affects intention to use eGovernment services. Cho [53] reached the same conclusion, arguing that repeated internet use for extended periods of time positively affects user behavior and system usage.

- Perceived risk has a negative effect on intention. This conclusion is in line with the studies of Lee [49] and Featherman and Pavlou [31]. For example, a loss of communication between user and server may have a negative impact on user trust and, therefore, in the intention to further use the online services.

- Peer influence positively affects intention. The same conclusion was reached by Hung, Chang and Yu [26]. A possible 'reward' from the immediate social environment predisposes the user towards using e-Government services.

- Moreover, computer self-efficacy has a direct positive effect on intention. Wangpipatwong, Chutimaskul and Papasrator [1] argue that people with increased computer 
self-efficacy easily understand the functions of online services, thus increasing their confidence and their general intention to use such systems.

- In the same line as above, internet experience was found to have a quite strong impact on computer self-efficacy $(\mathrm{r}=0,76)$. It seems that experienced internet users believe that they are more capable of using their computer. Hence, internet experience affects intention both directly $(\mathrm{r}=0,13)$ and indirectly (through computer self-efficacy and perceived risk).

- Additionally, internet experience has both a direct and indirect effect on perceived ease of use. The same conclusion was reached by Cheong and Park [55]: the more time a user spends on the internet, the better his perception about the usability of the online platform.

- Perceived ease of use was found to have a direct positive effect on perceived usefulness, something that has been supported by, almost, every TAM study [9] [11] [49].

- The present study found that perceived usefulness has a positive impact on trust. In the same direction, Suh and Han [56] argued that when the user fully understands the usefulness of the online service, his confidence is being significantly increased.

- Furthermore, perceived ease of use was found to have a direct negative effect on perceived risk. This relationship was also identified by Hung, Chang and Yu [26], who concluded that users finding an online system easy to operate, believe that the overall risk of the transaction is quite small.
- On the same vein, perceived usefulness was found to have a negative effect on perceived risk. According to Bélanger and Carter [24], when a system is considered to be useful, it is also usually considered to be free of various risks.

\section{CONCLUSIONS}

\section{A. General conclusions}

The present study developed a novel research framework in order to identify the main factors affecting the intention to use e-Government services. This framework (research model) was tested on a sample of 547 internet users.

The main conclusion of the present study does not concern a certain research factor. On the contrary, the empirical results support that both research and empirical focus should be drawn towards managing a bundle of factors (dimensions), which seem to be highly interrelated. The statistical analysis that was conducted highlighted various new causal relationships between the independent factors of the study. Therefore, one should not only pay attention to enhancing a limited number of factors, since the existence of various indirect effects underlined the need for a more integrated approach.

\section{B. e-Government user profile}

The average user has the following characteristics: (a) is under the age of 40, (b) is quite educated, (c) his monthly income is satisfactory, (d) uses e-Government services for more than a year, (e) uses e-Government services in order to gather information and conduct transactions, (f) makes about five transactions each month.

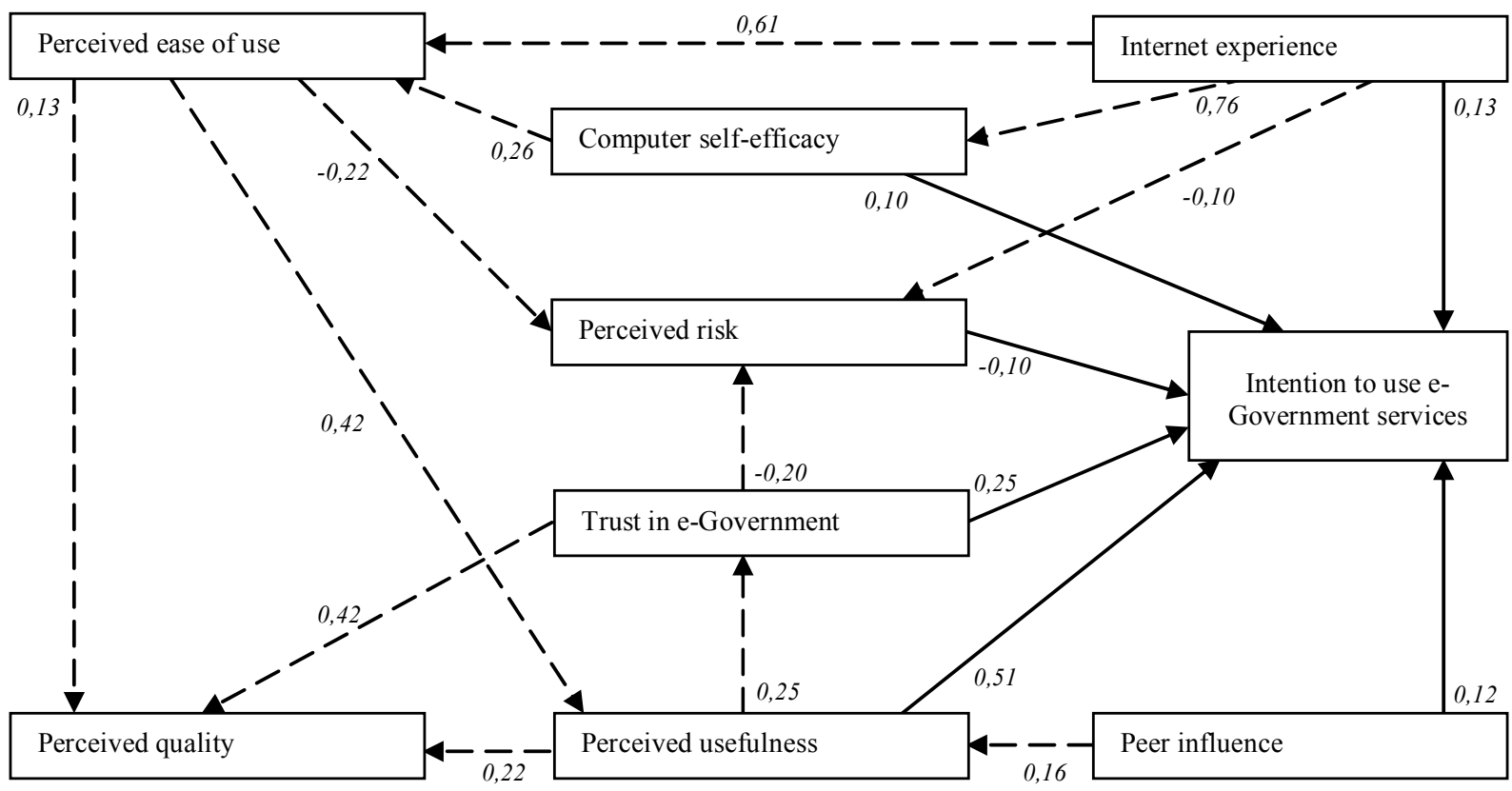

Fig 1. The modified conceptual framework of the study. 


\section{Managerial implications}

The empirical results showed that computer self-efficacy is positively related with the intention to use e-Government services. That finding is in line with Compeau and Higgins [45] and Wangpipatwong, Chutimaskul and Papasrator [1]. State officials should make efforts to fight computer illiteracy (seminars, incentives, etc), since only self efficient citizens will adopt e-Government.

Moreover, since trust is an essential element for the adoption of e-government, citizens should be convinced that state mechanisms are in place in order to protect their privacy and transactions in an impersonal medium, such as the internet. According to Dashti, Benbasat and BurtonJoneset [27] those responsible for public electronic services, should implement mechanisms for increasing public trust (receiving and answering to questions / comments, offer support via the phone, implement safety protocols, etc).

Additionally, according to Hung, Chang and $\mathrm{Yu}$ [26], external resources, such as television / news, significantly influence early-adopters and non-adopters of e-Government. By providing proper information to citizens (through the internet or in the form of leaflets), the state can bend the bias that exists towards online services [61] [62].

Finally, special focus should be given in enhancing the level of perceived usefulness [57]. Citizens are more interested in usefulness, as the effect of perceived ease of use is often reduced after a short period of time. In that direction, e-Government services should add value to citizens, offering access to useful information. There is no meaning in developing services that offer very little information and utility, while at the same time discourage citizens from future use. A useful application will attract the attention of the public and create more users in the near future.

\section{Limitations and future research}

The present research used self-reported scales in order to measure the constructs of the proposed framework. This is a limitation inherent to all explanatory studies. Moreover, the sample of the study is national (Greece), while, on the other hand, an international sample would provide results that could be generalized to the international context. Finally, future studies could take the empirical results of the present study into consideration and further enhance its proposed conceptual framework.

\section{REFERENCES}

[1] S. Wangpipatwong, W. Chutimaskul, and B. Papasrator, "Understanding Citizen's Continuance Intention to Use e-Government Website: a Composite View of Technology Acceptance Model and Computer Self-Efficacy", Electronic Journal of e-Government, Vol. 6, No. 1, pp. 55-64, 2008.

[2] O.K. Lean, S. Zailani, T. Ramayah, and Y. Fernando, "Factors influencing intention to use e-government services among citizens in Malaysia”, International Journal of Information Management, Vol. 29, No. 6, pp. 458-475, 2009, http://dx.doi.org/10.1016/j.ijinfomgt. 2009.03.012.
[3] E Ziemba, T. Papaj, and M. Jadamus-Hacura, "Critical success factors for adopting state and local e-government polish insights", in Proc. 13th International Conference e-Society 2015, Portugal, 2015, pp. 95102.

[4] S. Sang, J.-D. Lee, and J. Lee, "E-government adoption in ASEAN: the case of Cambodia", Internet Research, Vol. 19, No. 5, pp. 517534, 2009, http://dx.doi.org/10.1108/10662240910998869.

[5] L. Carter, and F. Bélanger, "The utilization of e-government services: citizen trust, innovation and acceptance factors", Information Systems Journal, Vol. 15, No. 1, pp. 5-25, January 2005, http://dx.doi.org/10.1111/j.1365-2575.2005.00183.x.

[6] V. Bekkers, "E-government and the emergence of virtual organizations in the public sector", Information Policy, Vol. 8, pp. 89101, 2003.

[7] H.-S. Doong, H.-C. Wang, and G. Foxall, "Psychological traits and loyalty intentions towards e-Government services", International Journal of Information Management, Vol. 30, No. 5, pp. 457-464, 2010, http://dx.doi.org/10.1016/j.ijinfomgt.2010.01.007.

[8] M. Rogers, Diffusion of innovations, $5^{\text {th }}$ ed., New York: the Free Press, 2003.

[9] C.W. Phang, Y. Li, J. Sutanto, and A. Kankanhalli, "Senior citizens' adoption of E-government: in quest of the antecedents of perceived usefulness", HICSS 2005, Proceedings of the 38th Annual Hawaii International Conference, IEEE, pp. 130a-130a, 2005, http://dx.doi.org/10.1109/HICSS.2005.538.

[10] V. Venkatesh and F. Davis, "A Theoretical Extension of the Technology Acceptance Model: Four Longitudinal Field Studies", Management Science, Vol. 46, No. 2, pp. 186-204, February 2000, http://dx.doi.org/10.1287/mnsc.46.2.186.11926.

[11] F.D. Davis, "Perceived Usefulness, Perceived Ease of Use, and User Acceptance of Information Technology", MIS Quarterly, pp. 319-340, September 1989, http://dx.doi.org/10.2307/249008.

[12] M. Fishbein and I. Ajzen, Belief, attitude, intention and behaviour: An introduction to theory and research, Massachusetts: Wesley, 1975.

[13] E.L. Deci, Intrinsic motivation, New York: Plenum Press, 1975.

[14] I. Ajzen, "Nature and operation of attitudes", Annual Review of Psychology, Vol. 52, No. 1, pp. 27-58, 2001, http://dx.doi.org/10.1146/annurev.psych.52.1.27.

[15] H.C. Triandis, Attitude and Attitude Change, New York: John Wiley, 1971.

[16] R.L. Thompson, C.A. Higgins, and J.M. Howell, "Personal computing: toward a conceptual model of utilization", MIS Quarterly, pp. 124-143, 1991, http://dx.doi.org/10.2307/249443.

[17] A. Bandura, "Self-efficacy mechanism in human agency", American Psychologist, Vol. 37, No. 2, pp. 122-147, 1982, http://dx.doi.org/10.1037/0003-066X.37.2.122.

[18] A. Bandura, Social foundations of thought and action: A social cognitive theory, Englewood Cliffs: Prentice Hall, 1986.

[19] J. Hiller, and F. Belanger, Privacy Strategies for Electronic Government, North America: Rowman and Littlefield Publishers, 2001.

[20] D.V. Dimitrova, and Y.-C. Chen, "Profiling the Adopters of EGovernment Information and Services: The Influence of Psychological Characteristics", Social Science Computer Review, Vol. 24, No. 2, pp. 172-188, 2006, http://dx.doi.org/10.1177/0894439305281517.

[21] E.M. Rogers, Diffusion of innovations, $4^{\text {th }}$ ed., New York: The Free Press, 1995.

[22] J.C. Thomas, and G. Streib, "The new face of government: Citizeninitiated contacts in the era of e-Government", Journal of Public Administration Research and Theory, Vol. 13, No. 1, pp. 83-102, 2003, http://dx.doi.org/10.1093/jpart/mug010.

[23] D.J. Atkin, L.W. Jeffres, and K. Neuendorf, "Understanding Internet Adoption as Telecommunications Behavior", Journal of Broadcasting \& Electronic Media, Vol. 42, No. 4, pp. 475-490, 1998, http://dx.doi.org/10.1080/08838159809364463.

[24] F. Bélanger, and L. Carter, "Trust and risk in e-government adoption", The Journal of Strategic Information Systems, Vol. 17, No. 2, pp. 165176, June 2008, http://dx.doi.org/10.1016/j.jsis.2007.12.002. 
[25] S. Colesca, "Increasing e-trust: a solution to minimize risk in the egovernment adoption", Journal of applied quantitative methods, Vol. 4, No. 1, pp. 31-44, 2009.

[26] S.-Y. Hung, C.-M. Chang, and T.-J. Yu, "Determinants of user acceptance of the e-Government services: The case of online tax filing and payment system", Government Information Quarterly, Vol. 23, No. 1, pp. 97-122, 2006, http://dx.doi.org/10.1016/j.giq.2005.11.005.

[27] A. Dashti, I. Benbasat, and A. Burton-Jones, "Developing trust reciprocity in electronic government: The role of felt trust", Proceedings of the European and Mediterranean Conference on Information Systems, Izmir, Turkey, pp. 1-13, 2009.

[28] M.T. Frolich, and R. Dixon, "A taxonomy of manufacturing strategies revisited", Journal of Operations Management, Vol. 19, No. 5, pp. 541-558, 2001, http://dx.doi.org/10.1016/S0272-6963(01)00063-8.

[29] R. Hubbard, D. Vetter, and E. Little, "Replication in strategic management: scientific testing for validity, generalizability, and usefulness", Strategic Management Journal, Vol. 19, No. 3, pp. 243254, 1998, http://dx.doi.org/10.1002/(SICI)10970266(199803)19:3<243::AID-SMJ951>3.0.CO;2-0.

[30] J.P. Peter, and M.J. Ryan, "An Investigation of Perceived Risk at the Brand Level", Journal of Marketing Research, pp. 184-188, May 1976, http://dx.doi.org/10.2307/3150856.

[31] M. Featherman, and P. Pavlou, "Predicting e-services adoption: a perceived risk facets perspective", International Journal of HumanComputer Studies, Vol. 59, No. 4, pp. 451-474, 2003, http://dx.doi.org/10.1016/S1071-5819(03)00111-3.

[32] J. Jacoby, and L.B. Kaplan, "The Components of Perceived Risk", Proceedings of the Third Annual Conference of the Association for Consumer Research, pp. 382-393, 1972.

[33] T. Kuisma, T. Laukkanen, and M. Hiltunen, "Mapping the reasons for resistance to Internet banking: A means-end approach", International Journal of Information Management, Vol. 27, No. 2, pp. 75-85, 2007, http://dx.doi.org/10.1016/j.ijinfomgt.2006.08.006.

[34] S. Forsythe, and B. Shi, "Consumer patronage and risk perceptions in Internet shopping", Journal of Business Research, Vol. 56, No. 11, pp. 867-875, 2003, http://dx.doi.org/10.1016/S0148-2963(01)00273-9.

[35] N. Reavley, "Securing online banking”, Card Technology Today, pp. 12-13, October 2005, http://dx.doi.org/10.1016/S09652590(05)70389-3.

[36] D. Littler and D. Melanthiou, "Consumer perceptions of risk and uncertainty and the implications for behaviour towards innovative retail services: The case of Internet Banking", Journal of Retailing and Consumer Services, Vol. 13, No. 6, pp. 431-443, 2006, http://dx.doi.org/10.1016/j.jretconser.2006.02.006.

[37] M.A. Eastlick, and S. Lotz, "Profiling potential adopters and nonadopters of an interactive electronic shopping medium", International Journal of Retail \& Distribution Management, Vol. 27, No. 6, pp. 209-223, 1999, http://dx.doi.org/10.1108/09590559910278560.

[38] G. Lohse, S. Bellman, and E. Johnson, "Consumer buying behavior on the Internet: findings from panel data", Journal of Interactive Marketing, Vol. 14, No. 1, pp. 15-29, 2000, http://dx.doi.org/10.1002/(SICI)1520-6653(200024)14:1<15::AIDDIR2>3.0.CO;2-C.

[39] F. Heider, The Psychology of Interpersonal Relations, New York: Wiley, 1958.

[40] D. Gefen and D. Straub, "The Relative Importance of Perceived Ease of Use in IS Adoption: A Study of E-Commerce Adoption", Journal of the Association for Information Systems, Vol. 1, No. 1, Article 8, 2000.

[41] M. Sathye, "Adoption of internet banking by Australian consumers: an empirical investigation", International Journal of Bank Marketing, Vol. 17, No. 7, pp. 324-334, 1999, http://dx.doi.org/10.1108/02652329910305689.

[42] J. Rotter, "Generalized expectancies for interpersonal trust", American Psychologist, Vol. 26, No. 5, pp. 443-452, May 1971, http://dx.doi.org/10.1037/h0031464.

[43] Y.-H. Tan, and W. Thoen, "Toward a Generic Model of Trust for Electronic Commerce", International Journal of Electronic Commerce, Vol. 5, No. 2, pp. 61-74, Winter 2001, http://dx.doi.org/10.1080/10864415.2000.11044201.
[44] D.H. McKnight, V. Choudhury, and C. Kacmar, "Developing and Validating Trust Measures for e-Commerce: An Integrative Typology", Journal Information Systems Research, Vol. 13, No. 3, pp. 334-359, September 2002.

[45] D.R. Compeau, and C.A. Higgins, "Computer self-efficacy: development of a measure and initial test", MIS Quarterly, pp. 189211, June 1995, http://dx.doi.org/10.2307/249688.

[46] D. Aaker, Managing brand equity: Capitalizing on the value of a brand name, New York, 1991.

[47] T.E. Cheng, D.Y. Lam, and A.C. Yeung, "Adoption of internet banking: an empirical study in Hong Kong", Decision Support Systems, Vol. 42, No. 3, pp. 1558-1572, December 2006, http://dx.doi.org/10.1016/j.dss.2006.01.002.

[48] G. Gronier, and M. Lambert, "A model to measure the perceived quality of service in e-government", Public Research Centre Henri Tudor, Luxembourg, 2010.

[49] M.-C. Lee, "Factors influencing the adoption of internet banking: An integration of TAM and TPB with perceived risk and perceived benefit", Electronic Commerce Research and Applications, Vol. 8, No. 3, pp. 130-141, June 2009, http://dx.doi.org/10.1016/j.elerap.2008.11.006.

[50] G. Pires, J. Stanton, and A. Eckford, "Influences on the perceived risk of purchasing online", Journal of Consumer Behaviour, Vol. 4, No. 2, pp. 118131, December 2004, http://dx.doi.org/10.1002/cb.163.

[51] T. Pikkarainen, K. Pikkarainen, H. Karjaluoto, and S. Pahnila, "Consumer acceptance of online banking: an extension of the technology acceptance model", Internet Research, Vol. 14, No. 3, pp. 224-235, 2004, http://dx.doi.org/10.1108/10662240410542652.

[52] B.J. Corbitt, T. Thanasankit, and H. Yi, "Trust and e-commerce: a study of consumer perceptions", Electronic Commerce Research and Applications, Vol. 2, No. 3, pp. 203-215, Autumn 2003, http://dx.doi.org/10.1016/S1567-4223(03)00024-3.

[53] J. Cho, "Likelihood to abort an online transaction: influences from cognitive evaluations, attitudes, and behavioral variables", Information \& Management, Vol. 41, No. 7, pp. 827-838, September 2004, http://dx.doi.org/10.1016/j.im.2003.08.013.

[54] S. Taylor, and P.A. Todd, "Understanding Information Technology Usage: A Test of Competing Models", Information Systems Research, Vol. 6, No. 2, pp. 144-176, 1995, http://dx.doi.org/10.1287/isre.6.2.144.

[55] J.H. Cheong, and M.-C. Park, "Mobile internet acceptance in Korea", Internet Research, Vol. 15, No. 2, pp. 125-140, 2005, http://dx.doi.org/10.1108/10662240510590324.

[56] B. Suh, and I. Han, "Effect of trust on customer acceptance of Internet banking”, Electronic Commerce Research and Applications, Vol. 1, No. 3, pp. 247-263, 2002, http://dx.doi.org/10.1016/S15674223(02)00017-0.

[57] V. Venkatesh, M.G. Morris, G.B. Davis, and F.D. Davis, "User Acceptance of Information Technology: Toward a Unified View", MIS Quarterly, pp. 425-478, September 2003.

[58] Internetworldstats.com, European Union Statistics of Internet Usage, Accessed at 12-2-2015 from: http://www.internetworldstats.com/ europa.htm\#gr.

[59] E.K. Kelloway, Using LlSREL for Structural Equation Modeling: A Researcher's Guide, Thousand Oaks, CA: Sage, 1998.

[60] F. Hair, R. Anderson, R. Tatham, and W. Black, Multivariate Data Analysis with Readings, Prentice-Hall International: London, 1995.

[61] S. Alghamdi, and N. Beloff, "Towards a comprehensive model for eGovernment adoption and utilisation analysis: The case of Saudi Arabia", in Proc. 2014 Federated Conference on Computer Science and Information Systems (FedCSIS), Warsaw, 2014, pp. 1217-1225, http://dx.doi.org/10.15439/2014F146.

[62] E. Ziemba, T. Papaj, and D. Descours, "Assessing the quality of egovernment portals-the Polish experience", in Proc. 2014 Federated Conference on Computer Science and Information Systems (FedCSIS), Warsaw, 2014, pp. 1259-1267, http://dx.doi.org/10.15439/ $2014 \mathrm{~F} 121$. 